\title{
PREDIKSI TINGKAT KELULUSAN TEPAT WAKTU DENGAN METODE NAÏVE BAYES DAN K-NEAREST NEIGHBOR
}

\author{
Sidik Rahmatullah ${ }^{1}$, Ema Utami $^{2}$ \\ 1) Teknik Informatika ${ }^{2)}$ Magister Teknik Informatika \\ ${ }^{1)}$ STMIK Dian Cipta Cendikia Kotabumi, ${ }^{2)}$ Universitas AMIKOM Yogyakarta \\ J1. Negara No.03 Candimas Kotabumi Lampung Utara \\ E-mail : sidik@dcc.ac.id,emma@nrar.net
}

\begin{abstract}
ABSTRAK
Lulusan adalah status yang dicapai mahasiswa setelah menyelesaikan proses pendidikan sesuai dengan persyaratan kelulusan yang ditetapkan oleh program studi. Sebagai salah satu keluaran langsung dari proses pendidikan yang dilakukan oleh program studi, lulusan yang bermutu memiliki ciri penguasaan kompetensi akademik termasuk hard skills dan soft skills sebagaimana dinyatakan dalam sasaran mutu serta dibuktikan dengan kinerja lulusan di masyarakat sesuai dengan profesi dan bidang ilmu. Program studi yang bermutu memiliki sistem pengelolaan lulusan yang baik sehingga mampu menjadikannya sebagai human capital bagi progam studi yang bersangkutan.
\end{abstract}

Penelitian ini menggunakan metode data mining yang digunakan untuk memprediksi tingkat kelulusan mahasiswa menggunakan dua metode yaitu Naive Bayes dan K-Nearest Neighbor. Hasil dari penelitian ini dapat memprediksi mahasiswa tepat lulus atau terlambat. Uji coba dilakukan dengan menggunakan data lulusan mahasiswa S1 Sistem informasi STMIK Dian Cipta Cendikia Kotabumi sebanyak 600 data untuk training dan 180 data untuk testing. Hasil uji coba menunjukkan bahwa dengan menggunakan Naive Bayes menghasilkan akurasi sebesar 85\%, sedangkan menggunakan algoritma K-nearest neighbor menghasilkan akurasi sebesar $68.89 \%$.

Kata kunci: Naïve Bayes, K-Nearest Neighbor, Prediksi Ketepatan Waktu Lulus

Abstracts

Graduates is status reached students after completing the process of education in accordance with the requirements of graduation set by the study program. As one of the output is to directly from the process of education that have been undertaken by by the study program, a graduate of a who are fully dedicated rewarded with lofty mansions in academic pt batubara bukit kendi total competence including a hard skills the and soft skills the as claimed in the target group quality and shall be proven with the performance of a graduate of $a$ in the midst of society in accordance with for a profession and the field of science. Course of study quality having management systems good graduates order to be able to make them a human capital for successor program study concerned.

This research uses the data mining used to measure graduation rates students using two method is naive bayes and k-nearest neighbor. The result of this research to predict students just pass or late.The trial was done using data from information system undergraduates stmik dian cipta cendikia kotabumi about 600 data for training and 180 data for testing The results of the tryouts shows that by the use of naïve bayes produce of accuracy of the numbers bayes as much as $85 \%$, while using an algorithm k-nearest neighbor produce of accuracy of the numbers as much as $68.89 \%$.

Keywords: naïve bayes, $k$-nearest neighbor, timeliness of students graduation prediction 


\section{PENDAHULUAN}

Dalam dunia pendidikan khususnya perguruan tinggi tidak lepas dengan adanya data yang menumpuk baik itu data mahasiswa dan juga data alumni, setiap tahun perguruan tinggi mengadakan penerimaan mahasiswa baru sehingga jumlah mahasiswa diperguruan tinggi akan semakin bertambah banyak. Sehingga perlu diperhatikan antara rasio mahasiswa yang ada dengan rasio dosen tetap pada program studi sesuai dengan surat edaran dari Kementerian Riset Teknologi dan Pendidikan Tinggi[1]

Berdasarkan [2] Lulusan adalah status yang dicapai mahasiswa setelah menyelesaikan proses pendidikan sesuai dengan persyaratan kelulusan yang ditetapkan oleh program studi. Sebagai salah satu keluaran langsung dari proses pendidikan yang dilakukan oleh program studi, lulusan yang bermutu memiliki ciri penguasaan kompetensi akademik termasuk hard skills dan soft skills sebagaimana dinyatakan dalam sasaran mutu serta dibuktikan dengan kinerja lulusan di masyarakat sesuai dengan profesi dan bidang ilmu. Program studi yang bermutu memiliki sistem pengelolaan lulusan yang baik sehingga mampu menjadikannya sebagai human capital bagi progam studi yang bersangkutan.

Perguruan tinggi seharusnya memiliki dan menerapkan kebijakan untuk mengelola dan mengevaluasi standar tersebut yaitu kelulusan mahasiswa yang mencerminkan kinerja perguruan tinggi dalam peningkatan mutu. Salah satu upaya yang dilakukan untuk mengelola kelulusan mahasiswa adalah tercapainya masa studi mahasiswa sesuai dengan lama studi yang telah terjadwal. Namun beberapa perguruan tinggi mengalami kesulitan bagaimana mahasiswa dapat mencapai masa studi tepat waktu sesuai dengan jadwal yang telah ditetapkan perguruan tinggi[3]

Berdasarkan hasil penelitian dari [4] Nä̈ve Bayes merupakan algoritma yang dapat digunakan untuk prediksi masa studi mahasiswa yang bisa dikategorikan tepat waktu, terlambat dan tidak lulus. Dengan menggunakan data mining khususnya klasifikasi untuk prediksi dengan algoritma naïve bayes dapat dilakukan prediksi terhadap ketepatan waktu studi dari mahasiswa berdasarkan data training yang ada. Pengujian yang dipakai yaitu $k$ fold cross validation 10-fold. Hasil pengujian didapat nilai akurasi rata-rata sebesar 85.17\% sedangkan nilai akurasi tertinggi sebesar $88.96 \%$.

Pada Penelitian [5] salah satu aspek pengukuran kualitas dalam evaluasi keberhasilan penyelenggaraan pendidikan tinggi adalah ketepatan lulus mahasiswa. Jumlah prosentase mahasiswa yang lulus tepat waktu menjadi indicator keberhasilan pelaksanaan proses belajar mengajar di suatu program studi. Penelitian ini menawarkan penggunaan metode data mining untuk memprediksi waktu lulus mahasiswa menggunakan dua metode yaitu k-nearest neighbor dan naïve bayes classifier. Hasil penelitian ini berupa system yang dapat memprediksi ketepata waktu lulus. Uji coba dilakukan dengan menggunakan data lulusan mahasiswa D3 Sistem informasi Universitas Airlangga. Hasil uji coba menunjukkan bahwa metode k-Nearest neighbor menghasilkan akurasi lebih tinggi dibandingkan dengan naïve bayes classifier. Akurasi tertinggi diperoleh dengan menggunakan metode k-nearest neighbor yaitu sebesar $98.7 \%$ oleh karena itu dapat disimpulkan bahwa system yang dibangun pada penelitian ini mampu memprediksi ketepatan waktu lulus dengan akurasi cukup tinggi.

Selanjutnya penelitian [6] menjelaskan Sistem Prediksi merupakan salah satu metode yang tepat untuk membentuk pola-pola yang mungkin dapat memberikan indikasi yang bermanfaat bagi pengelola perguruan tinggi sejak dini, sehingga pengelola dapat melakukan langkah-langkah positif dalam meminimalisasi masalah yang ada. Pada sistem prediksi ini dapat digunakan algoritma Nearest-Neighbor classifier dan Nä̈ve Bayes classifier dalam mengukur tingkat kelulusan kemungkinan mahasiswa lulus tepat waktu, tidak tepat waktu atau drop-out.

Dari uraian masalah diatas, maka penulis akan memprediksi tingkat kelulusan mahasiswa yang akan dapat membantu pihak akademik dalam mengelola dan mengevaluasi mutu dan kualitas yang berkaitan dengan kelulusan mahasiswa di lingkungan STMIK Dian Cipta Cendikia Kotabumi. Apabila masa studi dapat diprediksi dan hasil dari prediksi tersebut tidak sesuai atau melebihi masa studi yang seharusnya, maka pihak akademik dapat melakukan pencegahan dan membantu mahasiswa untuk dapat mengatasi kendala dalam mencapai kelulusan tepat waktu.

\section{METODE PENELITIAN}

\subsection{Metode Pengumpulan Data}

Dalam metode pengumpulan data ini, digunakan metode deskriptif yang bertujuan mengumpulkan data, menyajikan data dan membahas analisis data yang diperoleh.

a. Observasi

Melakukan pengamatan secara langsung terhadap kondisi yang ada di STMIK Dian Cipta Cendikia Kotabumi

b. Wawancara

Melakukan wawancara secara langsung terhadap pihak terkait yang ada di Perguruan Tinggi STMIK Dian Cipta Cendikia Kotabumi. 


\section{c. Studi Pustaka}

Dengan membaca buku-buku, literatur-literatur, melakukan pencarian melalui berbagai media terhadap apa saja yang berhubungan data mining maupun kelulusan mahasiswa sehingga lebih menambah referensi yang dibutuhkan.

\subsection{Metode Analis Data}

Tahap analisis data merupakan tahap preprocessing data terkait data yang akan diuji atau dievaluasi menggunakan machine learning. Tahap ini terdiri dari, pemilihan atribut atau fitur yang mendukung penelitian, data cleaning, dan menghasilkan data set berupa data training dan data testing yang nantinya akan dievaluasi.

Dalam penelitian ini akan dilakukan analisis data Prepocessing data yang dilakukan pada penelitian ini meliputi :

1. Penentuan data set

Pengelolaan Dataset yang didapatkan dari data bagian akademik data tersebut dalam bentuk Microsoft excel yang nantinya dapat diproses menggunakan rapidminer.

2. Penentuan Atribut

Dalam penentuan atribut dilakukan untuk menentukan perlu atau tidaknya atribut digunakan dalam proses klasifikasi.

3. Pembagian Dataset

Dataset keseluruhan dibagi menjadi dua bagian yakni data training dan data testing. Data training berisi 600 data sedangkan data testing berisi 180 data.

\section{Pemodelan}

Pembuatan model dari pelatihan data latih pada penelitian yakni menggunakan k-nearest neighbor dan naïve bayes. Masing-masing algoritma mempunyai tahapan algoritma klasifikasi masingmasing. Pembuatan model dibuat dengan mengikuti algoritma masing-masing. Aplikasi yang digunakan untuk melakukan pemodelan yaitu Rapidminer.

\section{Evaluasi dan Hasil}

Di dalam tahap evaluasi dan perbandingan dilakukan pengujian data uji sesuai masing-masing algoritma klasifikasi yaitu k-nearest neighbor dan naïve bayes. Untuk pengujian data uji menggunakan algoritma knn maka dilakukan penentuan nilai $\mathrm{k}$ berdasarkan percobaan nilai k pada angka tertentu. Setelah itu, menghitung jarak terdekat antara data uji dengan data latih sesuai jumlah $\mathrm{k}$ yang telah didapatkan sebelumnya. Kemudian, mengurutkan jarak yang paling minimum sehingga data uji bisa dikategorikan ke dalam kelas tertentu.

\subsection{Alur Penelitian}

alur penelitian pertama adalah diambil data kelulusan mahasiswa prodi Sistem Informasi berikut atribut yang akan digunakan. Kemudian data di masukkan dan dilakukan praproses terlebih dahulu agar data tersebut dapat digunakan ke dalam metode klasifikasi yaitu K-Nearest Neighbor dan Naïve Bayes Classifier. Setelah itu dilakukan pemilihan data training dan data testing secara acak. Data training merupakan data yang digunakan untuk membuat model pengklasifikasi baik pada metode kNearest Neighbor dan Naïve Bayes Classifier. Model pengklasifikasi yang dihasilkan oleh data training selanjutnya digunakan untuk memprediksi kelas dari data testing, sehingga pada data testing label kelas tidak digunakan. Hasil prediksi berupa label kelas akan dibandingkan dengan label kelas sebenarnya untuk dihitung akurasi metode baik knearest neighbor maupun Naïve bayes classifier.

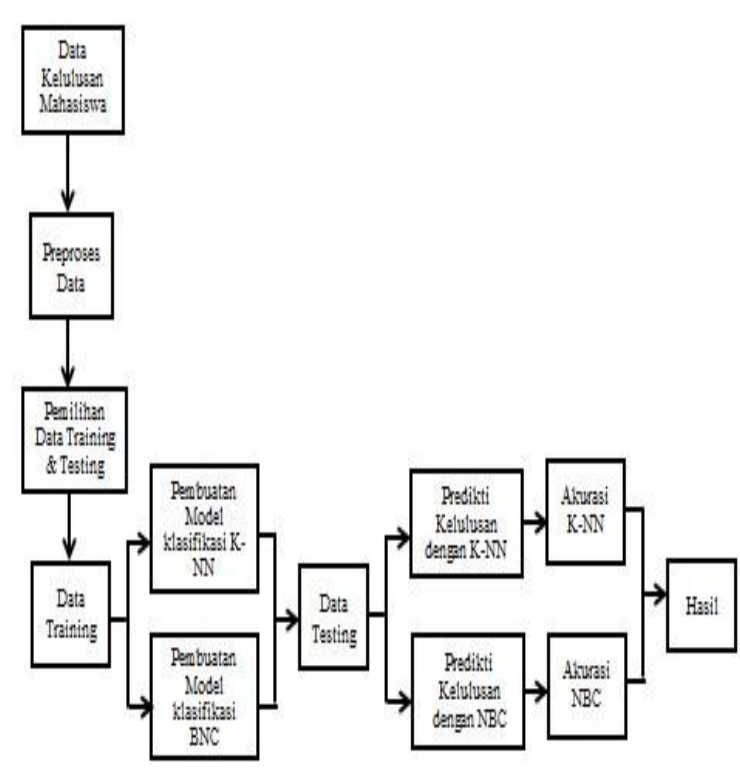

Gambar 1. Alur Penelitian

\section{HASIL DAN PEMBAHASAN}

\subsection{Dataset}

Sebelum melakukan proses perhitungan algoritma, terlebih dahulu dilakukan pengumpulan data. Masalah yang akan diolah datanya dalam pembahasan ini adalah memprediksi tingkat kelulusan mahasiswa prodi Sistem Informasi di STMIK Dian Cipta Cendikia Kotabumi. Data lulusan yang digunakan adalah 600 lulusan yaitu angkatan 2012 - 2013. Atribut-atribut data yang digunakan adalah NPM, Jenis Kelamin, IPS 1-5, Konsentrasi, asal tinggal, jumlah sks, status pekerjaan, status kelulusan.

Adapun data Training yang digunakan adalah sebanyak 600 data kelulusan pada program studi S1 Sistem Informasi angkatan 2012 - 2013. 
Tabel 1. Cuplikan Data Training Kelulusan

\begin{tabular}{|c|c|c|c|c|c|c|c|c|c|c|c|c|}
\hline & $\mathrm{Npm}$ & $\begin{array}{c}\text { Jenis_Kel| } \\
\text { amin }\end{array}$ & 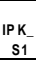 & $\mid \begin{array}{ll}P_{2} \\
\mathrm{~S} 2\end{array}$ & 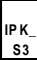 & $\begin{array}{l}\text { IPK K- } \\
\text { S4 }\end{array}$ & $\mid \begin{array}{c}P_{1} \\
\mathrm{~S}_{5} \\
\end{array}$ & 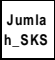 & $\begin{array}{l}\text { Kons } \\
\text { entra }\end{array}$ & $\begin{array}{c}\text { Status_k } \\
\text { erjia }\end{array}$ & $\begin{array}{c}\text { Asal-Ting } \\
\text { gal }\end{array}$ & $\begin{array}{c}\text { Statusus_t } \\
\text { lus }\end{array}$ \\
\hline & 1807011 & Laki & 3.11 & 3.6 & 3.4 & 18 & 1 & 10 & EIS & Bekerja & Luar & Tepat Wakt \\
\hline & 30701015 & Perempluan & 321 & 3.26 & \begin{tabular}{|l|l}
3.42 \\
\end{tabular} & 3 & 3.36 & 118 & EIS & Bekerja & Luar & Tepat Wakt \\
\hline & 8071020 & Laki & 3.14 & 3.52 & 3.17 & 3.25 & 2.45 & 10 & EDS & Bekeja & Luar & Tepat Wak \\
\hline & B0771025 & Laki & 2.96 & 3.35 & \begin{tabular}{|l|} 
\\
\end{tabular} & 3.18 & 1.45 & 90 & & Tirdak Bekeria & Luar & Terlambat \\
\hline & 8077330 & Perempuan & 3 & 3.17 & 2.82 & 3.27 & 3.35 & 110 & EIS & Tidakak Bekeris & Kotabumi & Tepat Wak \\
\hline & Bo71034 & $\begin{array}{l}\text { Laki } \\
\end{array}$ & 2.91 & 2.76 & 2.67 & 17 & \begin{tabular}{|l|l|} 
\\
\end{tabular} & 10 & EDS & Tidak Beker & $\begin{array}{ll}\text { Luar } \\
\end{array}$ & Tepat Wakt \\
\hline 7 & 3071044 & Perempuan & 3.5 & 3.3 & 3.33 & 3.5 & 3.39 & 118 & EIS & Tidak Bekeris & Kotabumi & Tepat Wakt \\
\hline 8 & 807057 & Perermpuan & 3.36 & 3.33 & 3.25 & 3.5 & 3.55 & 118 & EIS & Bekerja & Luar & Tepat Waki \\
\hline 9 & 8071065 & Laki & 3.04 & 2.26 & 2.67 & 2.82 & 191 & 100 & EDS & Tidak Bekerej & Luar & Tepat Wakt \\
\hline 10 & 80707073 & Perermpuan & 3.23 & 3.62 & 3.08 & 3.42 & 3.45 & 18 & EIS & Tidak Bekerie & Luar & Tepat Waki \\
\hline if & 30707071 & Perempuan & 15 & 17 & 2.08 & 2.33 & 3.1. & 80 & EIS & Tididak Bekerei & Kotabumi & Tepat War \\
\hline 12 & B07717078 & mpuan & 2.33 & 2.3 & 183 & 3.17 & 3.39 & 10 & EIS & Bekerja & Kotabumi & Tepat W \\
\hline 13 & B0771085 & Perempuan & 3.36 & 3.37 & 2.5 & 3.08 & 3.55 & 18 & EIS & Bekeria & Luar & Tepat Wakt \\
\hline 14 & B071092 & Laki & 3.61 & 3.83 & 3.67 & 3.73 & 2.64 & 18 & EIS & Tidak Bekerej & Luar & Tepat Waki \\
\hline 15 & 3007102 & Perempuan & 2.92 & 2.9 & 2.8 & 3.09 & \begin{tabular}{|l|}
3.35 \\
\end{tabular} & 188 & EIS & Tirdak Bekerej & Kotabumi & Tepat Wak \\
\hline 16 & 3071104 & Perempuan & 3.61 & 3.65 & 3.83 & 3.55 & \begin{tabular}{|l}
.91 \\
\end{tabular} & 118 & EIS & Bekeria & Luar & Tepat Wak \\
\hline 17 & 13071116 & Laki & 3.79 & 3.57 & 3.5 & 157 & 2.5 & 118 & EIS & Bekerja & Luar & T'e \\
\hline 18 & 10071117 & Laki & 2.59 & 2.95 & 3.83 & 3.67 & \begin{tabular}{|l|}
3.82 \\
\end{tabular} & 118 & EIS & Bekeria & Luar & Tepat Wak \\
\hline 19 & 3007182 & Perempuan & 3.43 & 3.43 & \begin{tabular}{|l|}
3.67 \\
\end{tabular} & 3.64 & \begin{tabular}{|l|}
3.82 \\
\end{tabular} & 118 & EIS & Bekerja & Luar & Tepat Wak \\
\hline 20 & $3007+140$ & Perempuan & 3.43 & 3.7 & 3.58 & 3.55 & \begin{tabular}{|l|}
2.6 \\
\end{tabular} & 18 & EIS & Bekeja & Luar & Tepat Waki \\
\hline 21 & $3007+146$ & Laki & 3.5 & 2.86 & 2.42 & 3 & 2.36 & 100 & EDS & Tidak Bekerej & Luar & Tepat Wakc \\
\hline 22 & 1307154 & Laki & 2.25 & 2.22 & 2.08 & 3.17 & 3.74 & 110 & EIS & Bekerja & Kotabumi & Tepat Wak \\
\hline 23 & 3071162 & Perempuan & 3 & 3.65 & 3.25 & 3.42 & \begin{tabular}{|l|}
3.57 \\
\end{tabular} & 118 & EIS & Tridak Bekeria & Kotabumi & Tepat Wak \\
\hline 24 & 3007169 & Perempuan & 3.17 & 2.61 & 2.58 & 3.25 & 3.57 & 118 & EIS & Tididak Bekeria & Kotabumi & Tepat Wa \\
\hline 25 & 3074453 & Laki & 2.76 & 196 & 2.5 & 3.08 & \begin{tabular}{|l|}
3.39 \\
\end{tabular} & 100 & EIS & Tidak Bekerie & Kotabumi & Tepat Wak \\
\hline 26 & 3071552 & Perempuan & 3.32 & 3.52 & 3.28 & 2.82 & \begin{tabular}{|l}
3.52 \\
\end{tabular} & 118 & EIS & Tidak Bekeris & Kotabumi & Tepat W \\
\hline 27 & 3071183 & Perempuan & 3.25 & 2.78 & 2.91 & 3.64 & 2.65 & 10 & EIS & Tidak Bekerei & Kotabumi & Tepat Wakt \\
\hline 28 & 13071192 & Laki & 2.74 & 3.04 & 3.09 & 191 & 3 & 48 & EIS & Tidiak Bekeri & Luar & Tepat Wakt \\
\hline 29 & B07195 & Laki & 2.92 & \begin{tabular}{|l|}
3.67 \\
\end{tabular} & 2.75 & 2.83 & 2.55 & 118 & EIS & Bekeja & Luar & Tepat \\
\hline . & 307200 & empuan & 3.5 & 3.43 & 2.55 & 2.9 & 3.35 & 118 & & & tabu & \\
\hline
\end{tabular}

Sedangkan untuk menguji menggunakan data testing sebanyak 180 data mahasiswa seperti yang tertera pada tabel 2. dibawah ini.

Tabel 2. Cuplikan Data Testing Mahasiswa

\begin{tabular}{|c|c|c|c|c|c|c|c|c|c|c|c|}
\hline No & $\mathrm{Npm}$ & $\underset{\substack{\text { JenisKelami } \\
\text { nela }}}{ }$ & \begin{tabular}{|c|c|}
$\mathrm{PK}_{-}$ \\
$\mathrm{S} 11$
\end{tabular} & 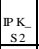 & $\begin{array}{c}\mathrm{PK} K_{-} \\
\mathrm{S} 3 \\
\end{array}$ & $\begin{array}{r}\text { PPK } \\
\text { S4 } \\
\end{array}$ & $\begin{array}{r}\mathbb{P r K}_{-} \\
\mathrm{S} 5\end{array}$ & $\begin{array}{c}\text { Jumlah } \\
\text { SKS } \\
\end{array}$ & $\begin{array}{c}\begin{array}{c}\text { onsen } \\
\text { trasi }\end{array} \\
\end{array}$ & Status_Ke rja & Asal_Tinggal \\
\hline 1 & 16071001 & Perempuan & 3.1 & 3.33 & \begin{tabular}{l|l}
3.42 \\
\end{tabular} & 3.6 & 3.4 & 18 & EIS & Tidak Bekerja & Kotabumi \\
\hline 2 & 16071002 & Perempuan & 3 & 3.25 & \begin{tabular}{|l|l}
3.42 \\
\end{tabular} & 3.6 & 3.3 & 118 & EIS & Tidak Bekeria & Kotabumi \\
\hline 3 & 16071003 & Perempuan & 2.95 & 3.25 & \begin{tabular}{|l|l}
3.25 \\
\end{tabular} & 3.8 & 3 & 118 & EIS & Tidak Bekeria & Kotabumi \\
\hline 4 & 16071004 & Perempuan & 3.25 & 3.33 & \begin{tabular}{|l|l|}
3.67 \\
\end{tabular} & 3.8 & 3.25 & 118 & EIS & Tidak Bekeria & Kotabumi \\
\hline 5 & 16071005 & Perempuan & 3 & 2.92 & \begin{tabular}{|l|l}
3.33 \\
\end{tabular} & 3.5 & 3 & 18 & EDS & Tidak Bekeria & Luar \\
\hline 6 & 16071006 & Perempuan & 3.1 & 3 & \begin{tabular}{|l|l}
3.5 \\
\end{tabular} & 3.7 & 3.3 & 18 & EDS & Tidak Bekeria & Kotabumi \\
\hline 7 & 16071007 & Laki & 2.8 & 1.15 & 124 & 0 & 0 & 80 & EDS & Tidak Bekerja & Luar \\
\hline 8 & 16071008 & Laki & 3 & 3.08 & 2.75 & 3.5 & 2.95 & 18 & EDS & Tidak Bekerja & Luar \\
\hline 9 & 16071009 & Laki & 2.5 & 1 & 1.5 & 1.8 & 2.85 & 10 & EIS & Tidak Bekerja & Luar \\
\hline 10 & 16071010 & Perempuan & 2.95 & 3.08 & 3 & 3.8 & 3.4 & 118 & EIS & Tidak Bekeria & Kotabumi \\
\hline 11 & 16071011 & Perempuan & \begin{tabular}{|l|}
3.1 \\
\end{tabular} & 3.17 & \begin{tabular}{|l|l}
3.42 & \\
\end{tabular} & 3.6 & 3.2 & 118 & EIS & Tidak Bekerja & Luar \\
\hline 12 & 16071012 & Perempuan & 2.75 & 2.58 & \begin{tabular}{|l|l}
175 \\
\end{tabular} & 1.1 & 2.85 & 110 & EIS & Tidak Bekeria & Luar \\
\hline 13 & 16071013 & Laki & 3.2 & 2.92 & \begin{tabular}{|l|l}
2.67 \\
\end{tabular} & 3.5 & 3.25 & 118 & EDS & Tidak Bekeria & Luar \\
\hline 14 & 16071014 & Laki & 1.95 & 2.25 & ${ }_{133}$ & 1 & 2.75 & 10 & EDS & Tidak Bekerja & Kotabumi \\
\hline 15 & 16071015 & Perempuan & 3 & 3.25 & 3.33 & 3.8 & 3.25 & 118 & EDS & Tidak Bekeria & Kotabumi \\
\hline 16 & 16071016 & Perempuan & 3.1 & \begin{tabular}{l|l}
3.42 \\
\end{tabular} & 3.5 & 3.6 & 3.25 & 118 & EDS & Tidak Bekeria & Luar \\
\hline 17 & 16071017 & Perempuan & 3.1 & 3.17 & \begin{tabular}{|l|l}
3.42 \\
\end{tabular} & 3.9 & 3.3 & 118 & EIS & Tidak Bekeria & Luar \\
\hline 18 & 16071018 & Laki & 2.95 & 2.67 & \begin{tabular}{|l|l}
3.33 \\
\end{tabular} & 2.7 & 3 & 10 & EIS & Tidak Bekerja & Luar \\
\hline 19 & 16071019 & Laki & 2 & 2 & \begin{tabular}{|l|l}
1 \\
\end{tabular} & 2 & 0 & 10 & EDS & Tidak Bekerja & Luar \\
\hline 20 & 16071020 & Laki & 2 & 1.5 & 0 & 0 & 0 & 60 & EDS & Tidak Bekerja & Luar \\
\hline
\end{tabular}

\subsection{Perhitungan Manual Algoritma Naive Bayes Clalssifier}

Langkah-langkah perhitungan manual algoritma Naïve Bayes Classifier dan pendukungnya dapat di lihat dibawah ini :

1. Menentukan Prior Probability (P)

Berdasarkan data training kelulusan yang digunakan maka akan dicari kelas kelulusan tepat waktu dan terlambat seperti pada Tabel 3
Tabel 3. Data Kelulusan Mahasiswa

\begin{tabular}{|l|c|}
\hline Kelulusan & Jumlah Kejadian \\
\hline Tepat Waktu & 354 \\
\hline Terlambat & 246 \\
\hline Jumlah & 600 \\
\hline
\end{tabular}

Menghitung jumlah kelas/label

$\mathrm{P}(\mathrm{Y}=$ Tepat Waktu $)$

$=354 / 600=0,59$

$\mathrm{P}(\mathrm{Y}=$ Terlambat $)$

$=246 / 600=0,41$

2. Menentukan Probabilitas kemunculan setiap nilai untuk atribut Jenis Kelamin (X1),

Konsentrasi (X8), Status Pekerjaan (X9), Asal Tinggal (X10)

a. Menentukan probabilitas kemunculan setiap nilai untuk atribut Jenis Kelamin (X1)

Dalam menentukan probabilitas kemunculan atribut jenis kelamin berdasarkan data training maka diperoleh hasil kemunculan seperti yang terlihat pada tabel 4

Tabel 4. Data Jenis Kelamin

\begin{tabular}{|l|c|c|}
\hline \multirow{2}{*}{$\begin{array}{c}\text { Jenis } \\
\text { Kelamin } \\
\text { X1 }\end{array}$} & \multicolumn{2}{|c|}{ Jumlah Kejadian } \\
\cline { 2 - 3 } & $\begin{array}{c}\text { Tepat } \\
\text { Waktu }\end{array}$ & Terlambat \\
\hline Laki & 191 & 139 \\
\hline Perempuan & 163 & 107 \\
\hline Jumlah & 354 & 246 \\
\hline
\end{tabular}

$\mathrm{P}($ Jenis Kelamin $=$ Laki $\mid \mathrm{Y}=$ Tepat Waktu $)$

$=191 / 354=0.540$

$\mathrm{P}($ Jenis Kelamin = Laki $\mid \mathrm{Y}=$ Terlambat $)$

$=139 / 246=0.565$

$\mathrm{P}($ Jenis Kelamin $=$ Perempuan $\mid \mathrm{Y}=$ Tepat Waktu $)$

$=163 / 354=0.460$

$\mathrm{P}($ Jenis Kelamin $=$ Perempuan $\mid \mathrm{Y}=$ Terlambat $)$

$=107 / 246=0.435$

b. Menentukan probabilitas kemunculan setiap nilai untuk atribut Konsentrasi (X8)

Dari data training diatas di peroleh data konsentrasi seperti pada tabel 5

Tabel 5. Data Konsentrasi

\begin{tabular}{|l|c|c|}
\hline \multirow{2}{*}{$\begin{array}{c}\text { Konsentrasi } \\
\text { X8 }\end{array}$} & \multicolumn{2}{|c|}{ Jumlah Kejadian } \\
\cline { 2 - 3 } & $\begin{array}{c}\text { Tepat } \\
\text { Waktu }\end{array}$ & Terlambat \\
\hline EIS & 218 & 142 \\
\hline EDS & 136 & 104 \\
\hline Jumlah & 354 & 246 \\
\hline
\end{tabular}

$\mathrm{P}($ Konsentrasi $=$ EIS $\mid \mathrm{Y}=$ Tepat Waktu $)$

$=218 / 354=0.616$

$\mathrm{P}($ Konsentrasi $=\mathrm{EIS} \mid \mathrm{Y}=$ Terlambat $)$

$=142 / 246=0.577$

$\mathrm{P}($ Konsentrasi $=$ EDS $\mid \mathrm{Y}=$ Tepat Waktu $)$

$=136 / 354=0.384$

$\mathrm{P}($ Konsentrasi $=\mathrm{EDS} \mid \mathrm{Y}=$ Terlambat $)$

$=104 / 246=0.423$ 
c. Menentukan probabilitas kemunculan setiap nilai untuk atribut Status Pekerjaan (X9)

Dari data training diatas di peroleh data Status Pekerjaan seperti pada tabel 6

Tabel 6. Data Status Pekerjaan

\begin{tabular}{|l|c|c|}
\hline \multirow{2}{*}{$\begin{array}{c}\text { Status } \\
\text { Pekerjaan } \\
\text { X9 }\end{array}$} & \multicolumn{2}{|c|}{ Jumlah Kejadian } \\
\cline { 2 - 3 } & $\begin{array}{c}\text { Tepat } \\
\text { Waktu }\end{array}$ & Terlambat \\
\hline Bekerja & 133 & 96 \\
\hline Tidak Bekerja & 221 & 150 \\
\hline Jumlah & 354 & 246 \\
\hline
\end{tabular}

$\mathrm{P}($ Status Pekerjaan $=$ Bekerja $\mid \mathrm{Y}=$ Tepat Waktu $)$ $=133 / 354=0.376$

$\mathrm{P}($ Status Pekerjaan $=$ Bekerja $\mid \mathrm{Y}=$ Terlambat $)$

$=96 / 246=0.390$

$\mathrm{P}($ Status Pekerjaan $=$ Tidak Bekerja $\mathrm{Y}=$ Tepat Waktu)

$=221 / 354=0.624$

$\mathrm{P}($ Status Pekerjaan $=$ Tidak Bekerja $\mid \mathrm{Y}=$ Terlambat $)$

$=150 / 246=0.610$

d. Menentukan probabilitas kemunculan setiap nilai untuk atribut Asal Tinggal (X9)

Dari data training diatas di peroleh data Asal Tinggal seperti pada tabel 7

Tabel 7. Data Kemunculan Asal Tinggal

\begin{tabular}{|l|c|c|}
\hline \multirow{2}{*}{$\begin{array}{c}\text { Asal Tinggal } \\
\text { X9 }\end{array}$} & \multicolumn{2}{|c|}{ Jumlah Kejadian } \\
\cline { 2 - 3 } & $\begin{array}{c}\text { Tepat } \\
\text { Waktu }\end{array}$ & Terlambat \\
\hline Kotabumi & 265 & 206 \\
\hline Luar & 89 & 40 \\
\hline Jumlah & 354 & 246 \\
\hline
\end{tabular}

$\mathrm{P}($ Asal Tinggal $=$ Kotabumi $\mid \mathrm{Y}=$ Tepat Waktu $)$ $=265 / 354=0.749$

$\mathrm{P}($ Asal Tinggal $=$ Kotabumi $\mid \mathrm{Y}=$ Terlambat $)$

$=206 / 246=0.837$

$\mathrm{P}($ Asal Tinggal $=$ Luar $\mid \mathrm{Y}=$ Tepat Waktu $)$

$=89 / 354=0.251$

$\mathrm{P}($ Asal Tinggal $=$ Luar $\mid \mathrm{Y}=$ Terlambat $)$

$=40 / 246=0.163$

e. Menghitung probabilitas untuk setiap kelas berdasarkan atribut dari kasus diatas akan dilakukan perhitungan dengan nilai probabilitas dari variabel yang bersifat kontinu yaitu IP_S1 (X2), IP_S2(X3), IP_S3(X4), IP_S4(X) 5), IP_S5(X6), Jumlah SKS (X7)

Berikut ini adalah perhitungan untuk mencari data mean dan standar deviasi untuk IPK_S1 sampai dengan IPK_S5 dan Jumlah SKS.
Tabel 8. Mean dan Standar Deviasi untuk setiap IPK Semester dengan masing-masing kategori

\begin{tabular}{|l|c|c|c|c|}
\hline \multirow{2}{*}{ Nama } & \multicolumn{2}{|c|}{ Standar Deviasi } & \multicolumn{2}{c|}{ Mean } \\
\cline { 2 - 5 } Atribut & $\begin{array}{c}\text { Tepat } \\
\text { Waktu }\end{array}$ & $\begin{array}{c}\text { Terlamb } \\
\text { at }\end{array}$ & $\begin{array}{c}\text { Tepat } \\
\text { Waktu }\end{array}$ & $\begin{array}{c}\text { Terlamb } \\
\text { at }\end{array}$ \\
\hline IPK_S1 & 0.43276 & 0.49548 & 2.81206 & 2.71166 \\
$($ X2) & 2 & 7 & 2 & 7 \\
\hline IPK_S2 & 0.33181 & 0.36955 & 2.94870 & 2.84268 \\
(X3) & 3 & 0 & 1 & 3 \\
\hline IPK_S3 & 0.28812 & 0.34047 & 2.87565 & 2.79682 \\
(X4) & 7 & 6 & 0 & 9 \\
\hline IPK_S4 & 0.32459 & 0.40973 & 2.88375 & 2.77012 \\
(X5) & 5 & 5 & 7 & 2 \\
\hline IPK_S5 & 0.39562 & 0.46901 & 2.92172 & 2.79207 \\
(X6) & 3 & 5 & 3 & 3 \\
\hline Jumlah & 10.6158 & 15.2483 & 111.870 & 110.524 \\
SKS & 82 & 33 & 1 & 4 \\
\hline
\end{tabular}

3. Menghitung Probabilitas dari setiap atribut Contoh Kasus Perhitungan menggunakan algoritma Naïve Bayes

1) Pengujian data testing mahasiswa Kasus 1 NPM : 16071001

$$
\begin{array}{lll}
X 1=\text { Perempuan } & X 4=3.42 & X 7=118 \\
X 2=3.10 & X 5=3.60 \quad X 8=E I S \\
X 3=3.33 & X 6=3.40 & \\
X 9=\text { Tidak Bekerja } & X 10=\text { Kotabumi }
\end{array}
$$

$\mathrm{P}(\mathrm{X} 1=$ Perempuan $\mid$ Tepat Waktu $)=163 / 354=0.460$

$\mathrm{P}(\mathrm{X} 1=$ Perempuan $\mid$ Terlambat $) \quad=107 / 246=0.435$

$\mathrm{P}(\mathrm{X} 2=3.10 \mid$ Tepat Waktu $)$

$$
\begin{aligned}
& =\frac{1}{\sqrt{2 \pi(0.492762)}} e \frac{-(a .10-2.812062)}{2(0.432762) 2}{ }^{2} \\
& =0.606564 \times 0.801439=0.486124
\end{aligned}
$$

$\mathrm{P}(\mathrm{X} 2=3.10 \mid$ Terlambat $)$

$$
\begin{aligned}
& =\frac{1}{\sqrt{2 \pi(0.495497)}} e \frac{-(2.10-2711667)}{2(0.495497)^{2}}{ }^{2} \\
& =0.566897 \times 0.735558=0.416985
\end{aligned}
$$

$\mathrm{P}(\mathrm{X} 3=3.33 \mid$ Tepat Waktu $)$

$$
\begin{aligned}
& =\frac{1}{\sqrt{2 \pi(0.391813)}} e \frac{-(a .3 a-2.949701)}{2(0.3 a 181 a)^{2}}{ }^{2} \\
& =0.692745 \times 0.516715=0.357952
\end{aligned}
$$$$
\mathrm{P}(\mathrm{X} 3=3.33 \mid \text { Terlambat })
$$$$
=\frac{1}{\sqrt{2 \pi(0.76955)}} e \frac{-(9.29-2.94269 \mathrm{a})}{2(0.36955)^{2}}
$$$$
=0.656418 \times 0.419188=0.275162
$$

$\mathrm{P}(\mathrm{X} 4=3.42 \mid$ Tepat Waktu $)$

$=\frac{1}{\sqrt{2 \pi(0.289127)}} e \frac{-(2.42-2.975650)}{2(0.289127)^{2}}$

$=0.743410 \times 0.16785=0.124781$

$\mathrm{P}(\mathrm{X} 4=3.42 \mid$ Terlambat $)$

$=\frac{1}{\sqrt{2 \pi(0.340476)}} e \frac{-(a .42-2.796829)^{2}}{2(0.340476)^{2}}$

$=0.6833875 \times 0.1877308=0.128096$ 
$\mathrm{P}(\mathrm{X} 5=3.60 \mid$ Tepat Waktu $)$

$=\frac{1}{\sqrt{2 \pi(0.324595)}} e \frac{-(3.60-2.892757)}{2(0.324595)^{2}}$

$=0.70041 \times 0.087641=0.061384$

$\mathrm{P}(\mathrm{X} 5=3.60 \mid$ Terlambat $)$

$=\frac{1}{\sqrt{2 \pi(0.409725)}} e \frac{-(2.92-27770127))^{2}}{2(0.3246)^{2}}$

$=0.623403 \times 0.128580=0.080162$

$\mathrm{P}(\mathrm{X6}=3.40 \mid$ Tepat Waktu $)$

$=\frac{1}{\sqrt{2 \pi(0.19562 a)}} e \frac{-(a .65-2.92172 a))^{2}}{2(0.39562 a)^{2}}$

$=0.634424 \times 0.481548=0.305505$

$\mathrm{P}(\mathrm{X6}=3.40 \mid$ Terlambat $)$

$=\frac{1}{\sqrt{2 \pi(0.469015)}} e \frac{-(a .65-2.79207 a)}{2(0.469015)^{2}}$

$=0.582676 \times 0.431691=0.251536$

$\mathrm{P}(\mathrm{X} 7=118 \mid$ Tepat Waktu $)$

$=\frac{1}{\sqrt{2 \pi(10.615992)}} e \frac{-(118-111.9701))^{2}}{2(10.615982)^{2}}$

$=0.122474 \times 0.846443=0.103667$

$\mathrm{P}(\mathrm{X} 7=118 \mid$ Terlambat $)$

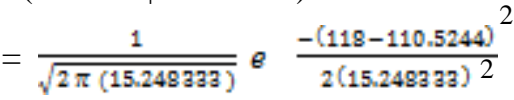

$=0.10219 \times 0.886764=0.090619$

$\mathrm{P}($ Konsentrasi $=$ EIS $\mid \mathrm{Y}=$ Tepat Waktu $)$

$=218 / 354=0.616$

$\mathrm{P}($ Konsentrasi $=\mathrm{EIS} \mid \mathrm{Y}=$ Terlambat $)$

$=142 / 246=0.577$

$\mathrm{P}($ Status Pekerjaan $=$ Tidak Bekerja $\mathrm{Y}=$ Tepat Waktu)

$=221 / 354=0.624$

$\mathrm{P}($ Status Pekerjaan $=$ Tidak Bekerja $\mid \mathrm{Y}=$ Terlambat $)$

$=150 / 246=0.610$

$\mathrm{P}($ Asal Tinggal $=$ Kotabumi $\mid \mathrm{Y}=$ Tepat Waktu $)$

$=265 / 354=0.749$

$\mathrm{P}($ Asal Tinggal $=$ Kotabumi $\mid \mathrm{Y}=$ Terlambat $)$

$=206 / 246=0.837$

4. Membandingkan hasil kelas Tepat Waktu dan Terlambat

Likelihood Tepat Waktu $=\mathrm{P}($ Perempuan|Tepat Waktu) * P(IPK_S1|Tepat Waktu) * P(IPK_S2|Tepat Wkatu) * P(IPK_S3|Tepat Waktu)

* P(IPK_S4|TepatWaktu) * P(IPK_S5|Tepat Waktu)

* P(Jumlah SKS|TepatWaktu $)$ * P(Konsentrasi|Tepat Waktu $) * \mathrm{P}($ Status Pekerjaan|Tepat Waktu $) * \mathrm{P}($ Asal Tinggal|Tepat Waktu)

Jadi : $0.460 * 0.486124 * 0.357952 * 0.124781 *$ $0.061384 * 0.305505 * 0.103667 * 0.616 * 0.624 *$ 0.749

$=0.00000559039$

Likelihood Terlambat $=\mathrm{P}($ Perempuan $\mid$ Terlambat $) *$ $\mathrm{P}\left(\mathrm{IPK} \_\mathrm{S} 1 \mid\right.$ Terlambat $) * \mathrm{P}\left(\mathrm{IPK} \_\mathrm{S} 2 \mid\right.$ Terlambat $)$ *
P(IPK_S3|Terlambat) * P(IPK_S4|Terlambat) * $\mathrm{P}\left(\mathrm{IPK} \_\right.$S5 $\mid$Terlambat $) * \mathrm{P}($ Jumlah SKS|Terlambat $)$ * $\mathrm{P}($ Konsentrasi|Terlambat $) \quad * \quad \mathrm{P}($ Status Pekerjaan|Terlambat $) * \mathrm{P}($ Asal Tinggal|Terlambat $)$

Jadi :

$0.727 * 0.416985 * 0.275162 * 0.128096 * 0.080162 * 0.2$

$51536 * 0.090619 * 0.577 * 0.609 * 0.609=$

0.00000344154

Jadi dari contoh kasus diatas bisa diprediksi bahwa mahasiswa tersebut diprediksi hasilnya adalah "Tepat Waktu" karena nilai likelihood Status lulus Tepat waktu lebih besar dibandingkan dengan Terlambat

\subsection{Contoh Kasus Perhitungan Manual Algoritma K-Nearest Neighbor}

Langkah-langkah perhitungan manual algoritma KNearest Neighboor pendukungnya dapat di lihat dibawah ini :

1. Pemberian Nilai Bobot untuk Tiap Kriteria Dalam pemberian bobot kriteria, dimana bobot antara satu kriteria dengan kriteria yang lain dapat didefinisikan dengan nilai yang berbeda. Berikut ini adalah contoh pemberian bobot pada kriteria indek prestasi semester (IPKS) $1-5$ dan jumlah SKS dimana nilai bobot digunakan untuk menghitung nilai kriteria.

Tabel 9. Nilai IPK Semester (IPS)

\begin{tabular}{|c|c|c|c|}
\hline No & Kriteria & Nilai & Bobot \\
\hline 1 & IPKS > $=3.5$ & $100=1$ & \multirow{4}{*}{$30 \%=0.3$} \\
\hline 2 & IPKS $>=3$ dan $<3.5$ & $80=0.8$ & \\
\hline 3 & IPKS $>=2$ dan $<3$ & $60=0.6$ & \\
\hline 4 & IPKS $<2$ & $40=0.4$ & \\
\hline
\end{tabular}

Nilai Kriteria IPKS adalah

Nilai

Kriteria

$\sum(100 \times 0.3)+(80 \times 0.3)+(60 \times 0.3)+(40 \times 0.3)$ $\mathrm{N}$

Nilai Kriteria $=\frac{30+24+18+12}{4}$

Nilai Kriteria $=\underline{84}$ 4

Nilai Kriteria $=21$

Tabel 10. Nilai Atribut Jumlah SKS

\begin{tabular}{|l|l|l|c|}
\hline No & \multicolumn{1}{|c|}{ Kriteria } & \multicolumn{1}{|c|}{ Nilai } & Bobot \\
\hline 1 & $<=120$ dan $>=115$ & $100=1$ & \multirow{2}{*}{$20 \%=0.2$} \\
\hline 2 & $<115$ dan $>=100$ & $80=0.8$ & \\
\hline 3 & $<=60$ dan $<100$ & $60=0.6$ & \\
\hline 4 & $>60$ & $40=0.4$ & \\
\hline
\end{tabular}

Nilai Kriteria Jumlah SKS adalah

Nilai Kriteria $=\sum(100 \times 0.2)+(80 \times 0.2)+(60 \times 0.2)+(40 \times 0.2)$ $\mathrm{n}$

Nilai Kriteria $=\underline{20+16+12+8}$

Nilai Kriteria $=\underline{56}$

Nilai Kriteria $=14$ 
Perhitungan yang sama dilakukan untuk semua kriteria dalam menentukan nilai dari kriteria-kriteria. Pada tabel 11 menunjukkan bobot untuk tiap kriteria yang digunakan.

Tabel 11. Bobot kriteria

\begin{tabular}{|l|l|l|}
\hline No & Atribut & Bobot \\
\hline 1 & IPKS & 0.3 \\
\hline 2 & Jenis Kelamin & 0.1 \\
\hline 3 & Jumlah SKS & 0.2 \\
\hline 4 & Konsentrasi & 0.1 \\
\hline 5 & Status Pekerjaan & 0.2 \\
\hline 6 & Asal Tinggal & 0.1 \\
\hline
\end{tabular}

\section{Menghitung Nilai Kedekatan Antar Kriteria}

Selanjutnya menentukan nilai kedekatan untuk semua kriteria, dimana nilai kedekatan adalah nilai yang berada pada jarak nilai antara 0 dan 1 . Nilai 0 berarti kedua kasus mutlak tidak mirip, dan untuk nilai 1 artinya kasus mirip secara mutlak. Nilai kedekatan akan digunakan untuk menghitung jarak terdekat antara data training dan data testing.

Berikut ini adalah tabel nilai kedekatan untuk kriteria IPK S :

Tabel 12. Nilai Kedekatan Kriteria IPK S

\begin{tabular}{|c|c|c|c|c|}
\hline IPKS & $>=35$ & $\begin{array}{c}>=3 \\
\text { dan } \\
<3.5\end{array}$ & $\begin{array}{c}>=2 \\
\text { dan }<3\end{array}$ & $\begin{array}{c}<2 \text { dan } \\
=<1\end{array}$ \\
\hline$>=35$ & 1 & 0.8 & 0.6 & 0.4 \\
\hline$>=3$ dan $<3.5$ & 0.8 & 1 & 0.75 & 0.5 \\
\hline$>=2$ dan $<3$ & 0.6 & 0.75 & 1 & 0.667 \\
\hline$<2$ dan $=<1$ & 0.4 & 0.5 & 0.667 & 1 \\
\hline
\end{tabular}

Selanjutnya untuk menentukan Nilai kedekatan untuk atribut Jumlah SKS

Tabel 13. Nilai Kedekatan Jumlah SKS

\begin{tabular}{|c|c|c|c|c|}
\hline Jumlah SKS & $\begin{array}{l}<=120 \\
\text { dan } \\
>=115\end{array}$ & $\begin{array}{l}<115 \\
\text { dan } \\
>=100\end{array}$ & $\begin{array}{l}<=60 \\
\text { dan } \\
<100\end{array}$ & $>60$ \\
\hline$<=120$ dan $>=11$ & 1 & 0.8 & 0.6 & 0.4 \\
\hline$<115$ dan $>=100$ & 0.8 & 1 & 0.75 & 0.5 \\
\hline$<=60$ dan $<100$ & 0.6 & 0.75 & 1 & 0.667 \\
\hline$>60$ & 0.4 & 0.5 & 0.667 & 1 \\
\hline
\end{tabular}

Berikut ini adalah Nilai kedekatan untuk Jenis Kelamin, Konsentrasi, Status Pekerjaan dan Asal Tinggal.

Pada masing-masing penentuan nilai kedekatan antar kriteria diperoleh nilai seperti pada Tabel 14, tabel 15, Tabel 16 dan Tabel 17.

Tabel 14. Nilai Kedekatan Jenis Kelamin

\begin{tabular}{|c|c|c|}
\hline Jenis Kelamin & Laki & Perempuan \\
\hline Laki & 1 & 0 \\
\hline Perempuan & 0 & 1 \\
\hline
\end{tabular}

Tabel 15. Nilai Kedekatan Konsentrasi

\begin{tabular}{|c|c|c|}
\hline Konsentrasi & EIS & EDS \\
\hline EIS & 1 & 0 \\
\hline EDS & 0 & 1 \\
\hline
\end{tabular}

Tabel 16. Nilai Kedekatan Status Pekerjaan

\begin{tabular}{|c|c|c|}
\hline Status Pekerjaan & Bekerja & $\begin{array}{c}\text { Tidak } \\
\text { Bekerja }\end{array}$ \\
\hline Bekerja & 1 & 0 \\
\hline Tidak Bekerja & 0 & 1 \\
\hline
\end{tabular}

Tabel 17. Nilai Kedekatan Asal Tinggal

\begin{tabular}{|c|c|c|}
\hline Status Pekerjaan & Kotabumi & Luar \\
\hline Kotabumi & 1 & 0 \\
\hline Luar & 0 & 1 \\
\hline
\end{tabular}

3. Perhitungan fungsi similarity

Selanjutnya dilakukan perbandingan antara data testing dan data training yang telah dipersiapkan sebelumnya dengan menggunakan rumus, dimana data testing ke-1 dibandingkan dengan kasus yang telah terjadi sebelumnya.

Data testing ke-1 NPM (16071002), dihitung nilainya berdasarkan tahapan-tahapan yang telah diulas sebelumnya. Berikut ini adalah contoh perhitungan dari tabel hasil perhitungan dengan kasus yang baru yaitu :

Menghitung kasus ke 1

a. Kedekatan jenis kelamin $=0$

b. Bobot kedekatan jenis kelamin $=0.1$

c. Kedekatan nilai IPK_S1 = 1

d. Kedekatan nilai IPK_S2 $=0.8$

e. Kedekatan nilai IPK_S3 = 1

f. Kedekatan nilai IPK_S4 $=0.4$

g. Kedekatan nilai IPK_S5 $=0.5$

h. Bobot kedekatan nilai IPKS $=0.3$

i. $\quad$ Kedekatan jumlah sks $=0.8$

j. $\quad$ Bobot kedekatan jumlah sks $=0.2$

k. Kedekatan konsentrasi $=1$

1. Bobot kedekatan konsentrasi $=0.1$

m. Kedekatan status pekerjaan $=0$

n. Bobot kedekatan status pekerjaan $=0.2$

o. Kedekatan asal tinggal $=0$

p. Bobot kedekatan asal tinggal $=0.1$

Menghitung (Kasus 1)

Jarak $=$

$\underline{(\mathrm{a} * \mathrm{~b})+(\mathrm{c} * \mathrm{~h})+(\mathrm{d} * \mathrm{~h})+(\mathrm{e} * \mathrm{~h})+(\mathrm{f} * \mathrm{~h})+(\mathrm{g} * \mathrm{~h})+(\mathrm{i} * \mathrm{j})+(\mathrm{k} * \mathrm{l})+(\mathrm{m} * \mathrm{n})+(\mathrm{o} * \mathrm{p})}$ $b+(5 * h)+j+l+n+q$

Jarak $=$

$(0 * 0.1)+(1 * 0.3)+(0.8 * 0.3)+(1 * 0.3)+(0.4 * 0.3)+(0.5 * 0.3)+($

$0.8 * 0.2)+(1 * 0.1)+(0 * 0.2)+(0 * 0.1)$

$0.1+(5 * 0.3)+0.2+0.1+0.2+0.1$ 
Jarak $=\frac{1.37}{2.2}$

Jarak $=0.622$

\subsection{Pengujian Model Algoritma Data Mining}

Dalam penyelesaian penelitian tentang prediksi kelulusan mahasiswa pada perguruan tinggi STMIK Dian Cipta Cendikia Kotabumi, metode yang digunakan adalah Nä̈ve Bayes dan K-nearest neighbor dengan 11 parameter yaitu 10 atribut dan 1 sebagai label yang terdiri dari Jenis Kelamin, IPK Semester 1 - IPK Semester 5, Jumlah SKS, Konsentrasi, Status Pekerjaan, Asal Tinggal dan label Tepat Waktu dan Terlambat.

\subsubsection{Pengujian Model Algoritma Naïve Bayes}

1. Proses Pengujian Model dengan Rapidminer Pengujian model Naive Bayes dengan menggunakan rapidminer akan menguji akurasi algoritma Nä̈ve Bayes, seberapa besar akurasi yang akan dihasilkan, hasil dari pengujian akurasi ini akan dibandingkan dengan metode lainnya.

Berikut ini adalah tahapan-tahapan yang dilakukan dalam pengujian dengan menggunakan performance untuk menghasilkan tingkat akurasi dan dari metode yang digunakan. Pengujian model Naive Bayes dengan menggunakan data training dan data testing seperti gambar 2

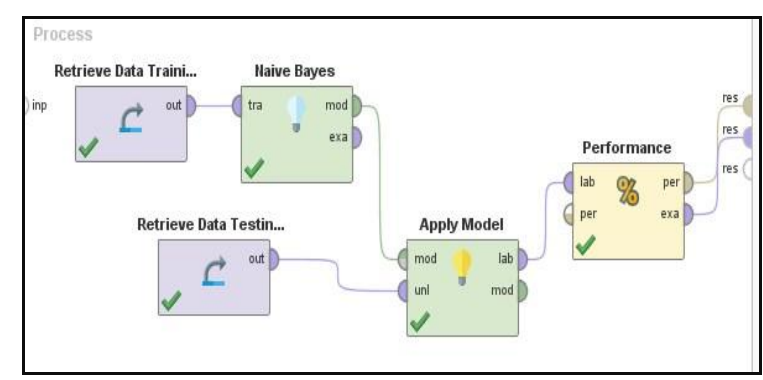

Gambar 2. Proses Pemodelan Algoritma Nä̈ve Bayes

Setelah dilakukan proses pemodelan dengan algoritma naïve bayes maka akan diperoleh prediksi dibawah ini :

\begin{tabular}{|c|c|c|c|c|c|c|c|}
\hline \multicolumn{4}{|c|}{ Erampleset (180 eramples, 4 special atrifibutes, 12 regular attibutes) } & \multicolumn{4}{|c|}{ Filter (180/190 eramples): all } \\
\hline - & Status_Lulus & prediction(Status_Lulus) & confidencer(Tepat... & confidencerererlambat) & ॥pm & Nama & Jenis_k \\
\hline 1 & Tepat Waitu & Tepat Waktu & 0.671 & 0329 & 16071001 & Anisa Agusin_. & Perempl' \\
\hline 2 & Tepat Wahu & Tepat Waktu & 0.678 & 0.322 & 16071002 & Arobana Saffiti & Perempl. \\
\hline 3 & Tepat Watu & Tepat Waktu & 0.569 & 0.431 & 160071003 & Dea Puspita & Perempl \\
\hline 4 & TepatWatu & Terlambat & 0.451 & 0.549 & 160711004 & DesiRestiana & Perempi. \\
\hline 5 & Tepat Waitu & Tepat Wału & 0.755 & 0245 & 16071005 & Devi OKassai & Perempi. \\
\hline 6 & Tepat Waitu & Tepat Wałtu & 0.549 & 0.451 & 16071006 & Diasmai Pus_. & Peremph \\
\hline 7 & Teliambat & Teflambat & 0 & 1 & 16071007 & Doni Pratama & Laki \\
\hline 8 & Tepat Waitu & Tepat Wału & 0.739 & 0261 & 160711008 & Fachin Pawiga & Lał \\
\hline 9 & Tepat Waltu & Terlambat & 0.000 & 1.000 & 16071009 & Finthan Hutab.. & Lali \\
\hline 10 & TepatWaatu & Tepat Waktu & 0.619 & 0381 & 160711010 & Indrijani & Perempu. \\
\hline 11 & Tenat Waiti & Tenat Wathi & ก78? & $n 218$ & 16071011 & Ierriatsina $P$ & Peramey \\
\hline
\end{tabular}

Gambar 3. Proses Hasil Pemodelan algoritma Naïve Bayes

2. Hasil Analisa Pengujian Model

Setelah proses pengujian model dengan data training sebanyak 600 data dan data testing sebanyak 180 data akan menghasilkan output accuracy sebesar $85.00 \%$ precision sebesar $44.90 \%$ dan recall sebesar $100 \%$ seperti yang terlihat pada gambar 4 dibawah ini.

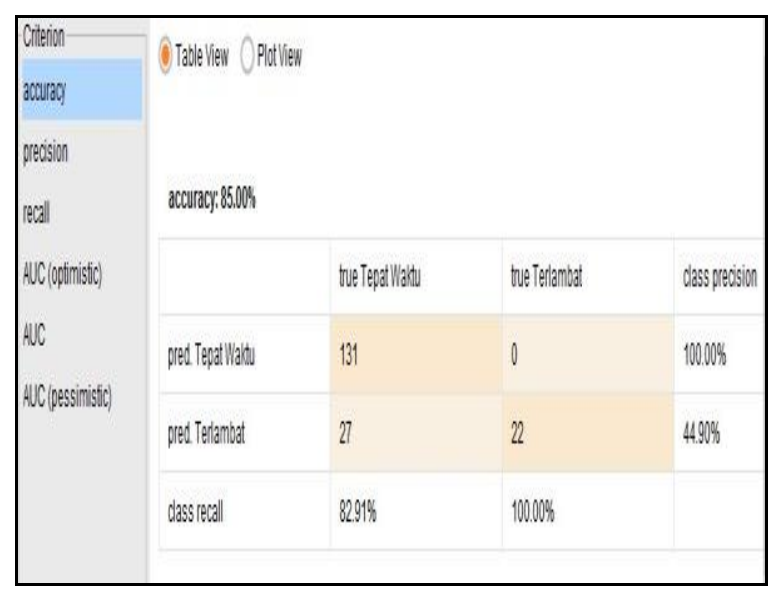

Gambar 4. Hasil Confusion Matrix Nä̈ve Bayes

Selanjutnya lebih jelasnya untuk hasil accuracy, precision, recall terlihat pada gambar 5

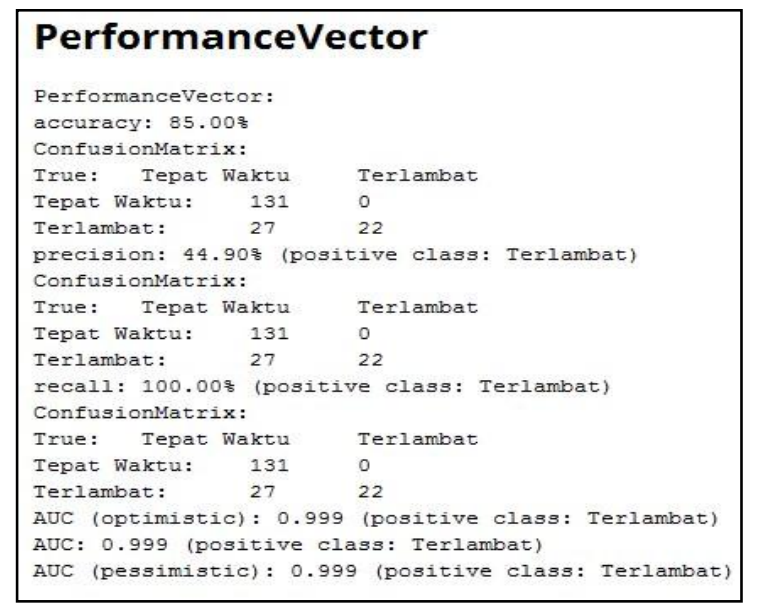

Gambar 5. Hasil Performance Vektor Nä̈ve Bayes

\subsubsection{Pengujian Model Algoritma K-nearest} neighbor

1. Proses Pengujian Model dengan Rapidminer

Pengujian model K-Nearest Neighbor dengan menggunakan rapidminer akan menguji akurasi algoritma K-Nearest Neighbor, seberapa besar akurasi yang akan dihasilkan, hasil dari pengujian akurasi ini akan dibandingkan dengan metode lainnya.

Berikut ini adalah tahapan-tahapan yang dilakukan dalam pengujian dengan menggunakan performance untuk menghasilkan tingkat akurasi dan dari metode yang digunakan. Pengujian model K-Nearest 
Neighbor dengan menggunakan data training dan data testing seperti gambar 6

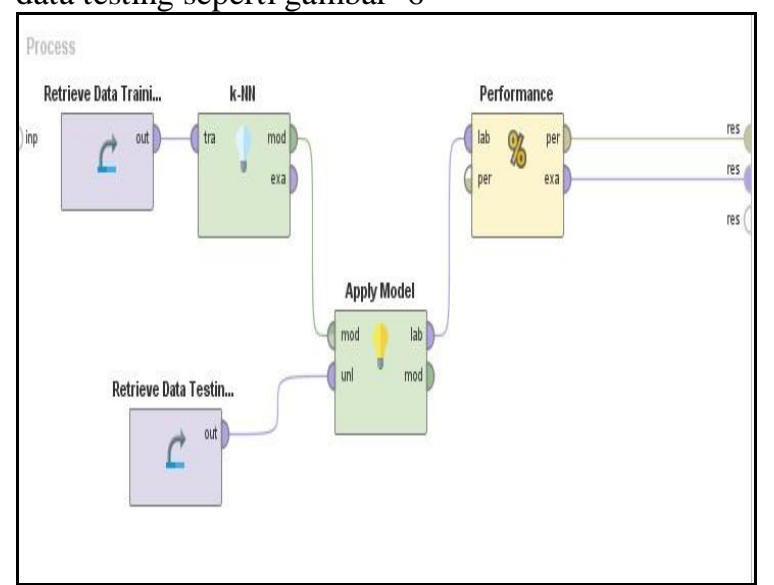

Gambar 6. Proses pengujian Algoritma K-Nearest Neighbor

Setelah dilakukan proses pemodelan dengan algoritma K-Nearest Neighbor maka akan diperoleh prediksi pada gambar 7 dibawah ini :

\begin{tabular}{|c|c|c|c|c|c|c|c|c|}
\hline \multicolumn{5}{|c|}{ 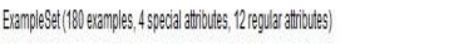 } & \multicolumn{2}{|c|}{ Filier(1900 / 180 eramples). } & \multicolumn{2}{|c|}{ all } \\
\hline Ro... & Status_Lulus & prediction/ $S_{\text {m. }}$ & confidenceflepat..... & confidencet(Terlambat) & $\| p m$ & Nlama & Jenis_Kela. & \\
\hline 1 & Tepat Wakiu & Tepat Waltu & 0788 & 0.212 & 16071001 & Anisa housin... & Premovan & \\
\hline 2 & Tepatillialtu & TepatWatu & 0.005 & 0.395 & 16071002 & Horana Satiti & Perempuan & \\
\hline 3 & TepatWaktu & TepatWalwu & 0596 & 0.404 & 16071003 & DeaPuspita & Perempuan & 2 \\
\hline 4 & Tepat Waliu & Tepat Wahtu & 0.604 & 0.396 & 16071004 & DesiRestiana & Perempuan & \\
\hline 5 & Tepat Waldu & TepatWalu & 0.595 & 0.405 & 160071005 & Dein Othasen & Prempuan & \\
\hline 6 & Tepatilliaku & TepatWahtu & 0.800 & 0.200 & 16071006 & Diasma Pusp & Peremouan & ? \\
\hline 7 & Tellambat & Tellambat & 0.187 & 0.813 & 16071007 & DoniPrialama & Laki & i \\
\hline 8 & TepatWakiu & Tepat Waitu & 0.599 & 0.401 & 16071008 & Fachin Pariga & Laki & , \\
\hline 9 & TepatWaktu & TepatWaltu & 0.001 & 0.399 & 16071009 & Filinan Hutabo.. & Laki & 2 \\
\hline 10 & Tepatillahtu & TepatWathu & 0.597 & 0.403 & 10071010 & Indriani & Perempuan & ? \\
\hline 11 & Tenat Wahtil & Tenat Wahtı & 1 & n & 160771011 & Ierrilatina Piti & Prromnizan & \\
\hline
\end{tabular}

Gambar 7. Proses Hasil Pemodelan Algoritma $K$ Nearest Neighbor

2. Hasil Analisa Pengujian Model

Setelah proses pengujian model, akan menghasilkan output accuracy seperti gambar 8 dibawah ini

\begin{tabular}{|c|c|c|c|c|}
\hline Citerion- & CO Toblelver $\bigcirc p$ & & & \\
\hline ocourdoy & & & & \\
\hline pression & & & & \\
\hline reall & accurace:68899\% & & & \\
\hline AUC (opfinisicic) & & the Tepal Hath & thu Telantobl & dassp perision \\
\hline$N U C$ & pred Tepall lathu & 112 & 10 & $9180 \%$ \\
\hline & pred Telantod & 46 & 12 & $20.99 \%$ \\
\hline & dass reabll & 708996 & $5455 \%$ & \\
\hline
\end{tabular}

Gambar 8. Hasil Confusion Matrix K-Nearest Neighbor

Dari gambar 8 memberikan informasi bahwa hasil accuracy dari metode klasifikasi K-Nearest Neighbor adalah sebesar $68.89 \%$. Untuk nilai precision adalah sebesar $20.69 \%$ dan nilai recall adalah sebesar $54.55 \%$.

\section{PerformanceVector}

PerformanceVector:

accuracy: $68.89 \%$

ConfusionMatrix:

True: Tepat Waktu Terlambat

Tepat Waktu: $112 \quad 10$

Terlambat: $\quad 46 \quad 12$

precision: 20.69\% (positive class: Terlambat)

ConfusionMatrix:

True: Tepat Waktu Terlambat

Tepat Waktu: $112 \quad 10$

Terlambat: $\quad 46 \quad 12$

recall: 54.55\% (positive class: Terlambat)

ConfusionMatrix:

True: Tepat Waktu Terlambat

Tepat Waktu: $112 \quad 10$

Terlambat: $\quad 46 \quad 12$

AUC (optimistic): 0.646 (positive class: Terlambat)

AUC: 0.646 (positive class: Terlambat)

AUC (pessimistic): 0.646 (positive class: Terlambat)

Gambar 9. Hasil Performance Vektor K-Nearest Neighbor 


\section{Kesimpulan}

Berdasarkan pembahasan yang telah diuraikan, yaitu tentang Predikti Tingkat Kelulusan Mahasiswa Dengan Metode Nä̈ve Bayes dan K-Nearest Neighbor untuk memprediksi tingkat kelulusan Tepat Waktu mahasiswa, maka dapat disimpulkan beberapa hal sebagai berikut:

1. Hasil pengujian pada perhitungan manual naïve bayes pada data testing ke-1 di prediksi hasilnya adalah tepat waktu

2. Hasil pengujian menggunakan naïve bayes menggunakan rapidminer dengan jumlah training 600 dan data testing 180 di dapat nilai akurasi sebesar $85 \%$

3. Hasil pengujian manual K-nearest neighbor pada testing ke-1 diprediksi hasilnya adalah tepat waktu.

4. Hasil pengujian menggunakan k-nearest neighbor menggunakan rapidminer dengan jumlah training 600 dan data testing 180 di dapat nilai akurasi sebesar $68.89 \%$

\subsection{Saran}

Saran yang ditambahkan untuk pengembangan dan penelitian selanjutnya adalah sebagai berikut :

1. Hasil penelitian ini perlu diimplementasikan menjadi perangkat lunak yang dapat digunakan oleh pihak STMIK Dian Cipta Cendikia Kotabumi untuk dapat memprediksi ketepatan waktu lulus mahasiswa.

2. Untuk penelitian mendatang, pemilihan algoritma klasifikasi selain naïve bayes dan knearest neighbor seperti C.45, support vector machine serta penggunaan teknik optimasi.

3. Selain atribut yang digunakan oleh penulis dalam melakukan penelitian, akan lebih baik menambahkan atribut selain yang penulis gunakan.

\section{DAFTAR PUSTAKA}

[1] Alannuary, Adis, 2015, Edaran Dikti Tentang Nisbah Rasio Dosen/Mahasiswa Di Atas 100, http://www.kopertis4.or.id/2015/08/edarandikti-tentang-nisbah-rasiodosenmahasiswa-di-atas-100

[2] BAN-PT, B. A., 2010, AKREDITASI PROGRAM STUDI DIPLOMA. Jakarta: BAN-PT.

[3] Windarti, M., 2016, Prediksi Masa Studi Mahasiswa Menggunakan Kombinasi Algoritma Bayesian Network Dan KNearest Neighbors (Doctoral dissertation, UAJY).
[4] Lumenta, A.S. and Jacobus, A., 2017. Prediksi Masa Studi Mahasiswa dengan Menggunakan Algoritma Naïve Bayes. JURNAL TEKNIK INFORMATIKA UNIVERSITAS SAM RATULANGI, 11(1).

[5] Novianti, A.G. and Prasetyo, D., PENERAPAN

$$
\begin{array}{lrr}
\begin{array}{l}
\text { ALGORITMA } \\
\text { NEIGHBOR }
\end{array} & \text { K-NEAREST } \\
\text { PREDIKSI } & \text { WAKTU } & \text { UNTUK } \\
\text { MAHASISWA. } &
\end{array}
$$

[6] Ginting, S.L.B., Zarman, W. and Darmawan, A., 2014. Teknik Data Mining Untuk Memprediksi Masa Studi Mahasiswa Menggunakan Algoritma K-Nearest Neighborhood. Jurnal Teknik Komputer Unikom, 3(2), pp.29-34. 